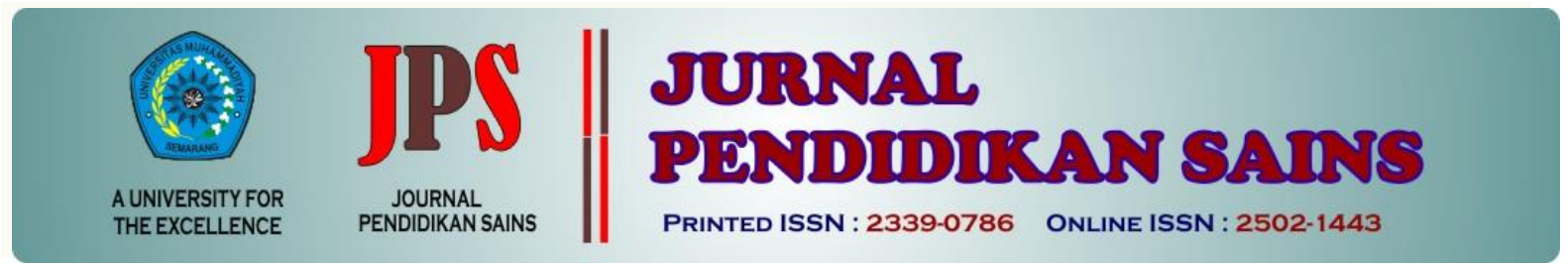

http://jurnal.unimus.ac.id/index.php/JPKIMIA

\title{
INFUSING ISLAMIC VALUES AND SUSTAINABLE DEVELOPMENT INTO CHEMISTRY FOR PRE-SERVICE ISLAMIC ELEMENTARY SCHOOL TEACHERS
}

\author{
Oleh \\ Muhamad Imaduddin \\ Institut Agama Islam Negeri Kudus
}

\begin{tabular}{ll}
\hline \multicolumn{2}{l}{ Article history } \\
\hline Submission & $: 2019-01-26$ \\
Revised & $: 2019-02-19$ \\
Accepted & $: 2019-03-16$
\end{tabular}

Keyword:

Keyword: Islamic Values; Sustainable Development; Chemistry for Pre-service Islamic Elementary School Teachers.

\begin{abstract}
This paper discusses about the designs in infusing Islamic values and sustainable development and how challenges must be faced in the training for pre-service islamic elementary school teachers. The subjects of this study consisted of 77 pre-service Islamic elementary school teachers who contracted "Simple Chemistry" lectures. The instrument was The Chemical Essay Test Integrated Sustainable Development Aspects (CET-SD) containing Islamic discourse. Based on pedagogical planning, lesson plans are divided into four stages, consisting of (1) phase of contact; (2) phase of curiosity and planning; (3) phase of elaboration; and (4) phase of deepening and networking. The relationship between Islamic values, chemistry and the environment was well understood by pre-service teachers. Some challenges in teaching chemical content were found regarding with (1) difficulties with the relation between macro domain and submicro domain; (2) difficulties with the relation between symbolic domain and macro or submicro domain; (3) difficulties with models.
\end{abstract}

\section{Introduction}

Science is the study of nature, including natural laws related to chemistry, physics, and biology, as well as the treatment or application of facts, principles, concepts, or conventions associated with these disciplines. Science is both a body of knowledge that has been accumulated over time and a processscientific inquiry-that generates new knowledge (NRC, 2009). The science literacy for all members of the community becomes so crucial including children and teenagers that they have been playing with technology that

*Corresponding Author:

Name : Muhamad Imaduddin

Institution : Institut Agama Islam Negeri Kudus

Email_:imad@iainkudus.ac.id their own parents have not necessarily mastered (Moore, 2008). The orientation of science educators should not be merely on the transfer of science content knowledge but also in how learners have literacy-on chemical, biological, and physical aspects-as a means of life in society. Therefore, the provision of science literacy in primary school teacher candidates is necessary so that in the future science can be presented more meaningfully to children. This includes also through a chemical learning program as part of science for pre-service islamic elementary school teachers. 
Like human rights, sustainable development can be regarded as an idea of arrangement for human and community life (Rauch, 2004). They provide direction for the research and learning process. The political arena has begun to place more emphasis on the global importance of sustainable development that has become influential for education. The UN announces the Decade of Education for Sustainable Development (DESD) for the years 2005-2014. The DESD is considered to play an important role in ESD's global implementation (Eilks, Rauch, Ralle, \& Hofstein, 2013, p. 14). It shows the promotion of understanding the interrelated nature of the economic, social and ecological aspects involved in community development (Burmeister, Rauch, \& Eilks, 2012). The guidelines for implementing the UN Decade define the following areas of strategic action: Equality between women and men, health promotion, environmental protection, rural development, peace and human security, sustainable consumption, cultural diversity, and sustainable urban development (UNESCO, 2006). Some of Indonesian cultural potentials can be foundation in SESD such as "Petri Tuk Babon" Tradition in Boyolali, "Panglima Laot" in Aceh, "Pranoto Mongso" in Java, Songket Melayu, "Usada Rara" Manuscript in Sasak, Lombok, and "Tuak" in Tradition from Batak (Imaduddin, 2018). The orientation of chemistry learning leading to sustainable development supports efforts in focusing the literacy aspects of learning.

On the different side, Islam upholds the basic goal of sustainable development and the creation of an environment that enables people to enjoy the spiritual, moral and socioeconomic welfare of the world and success in the afterlife (Clark \& Singh, 2016). Chemical literacy of learners as one form of welfare in the form of the acquisition of meaningful knowledge of the concept of chemistry has placed the need to link chemistry with Islamic values that have been learned by learners based on Quran, Hadith, and ijtihad ulama. This becomes important when the prospective teacher is facing the environment of learners who emphasize on religious coaching since the early as in the Integrated Islamic Elementary School or Madrasah Ibtidaiyyah (MI).

The challenge of learning chemistry for pre-service islamic elementary school teachers is that they had various knowledge of chemistry background. They came from social, natural sciences, language, and religion programs in the previous academic level. Although all are required to have the sufficiency of chemical literacy as pre-service islamic elementary school teachers that will transform science learning into more meaningful classes. Learning is considered a shift from a particular sociocultural environment that contains the knowledge and experiences of everyday life of the students to a new socio-cultural environment containing the experience and knowledge of school chemistry (Vygotsky, 1986). This transformation also includes the challenge of language changes: the old term gets a new meaning. In addition to previous perspectives, this point of view also emphasizes the importance of using adequate language in chemistry textbooks and classroom practice (Eilks et al., 2013, p. 98). This paper discusses about the designs in infusing Islamic values and sustainable development and how challenges must be faced in equipping pre-service islamic elementary school teachers.

\section{Methodology}

This research was mixed methods. Mix methods research combines quantitative and qualitative research methods in different ways, with each approach adding something to the understanding of the phenomenon (Ary, Jacobs, Sorensen, \& Razavieh, 2006, p. 559). This study described narratively the implementation of chemistry learning design and showed the quantitative results of the mastery of the contextual chemistry concept integrating with the aspects of Sustainable Development that have been achieved by pre-service islamic elementary school teachers. The subjects of this study consisted of 77 primary school educational candidates who contracted "Simple Chemistry" lectures at the Madrasah Ibtidaiyah Teachers Education program study at one of the universities in East Java. The instrument was The Chemical Essay Test Integrated Sustainable Development Aspects (CET-SD) containing Islamic discourse. The Chemistry instruction were designed with 16 sessions including two test sessions: mid-tests for chemistry content related to air and water environments, as well as final-test for chemicals related to water management technology, and soil components. The instruction were presented through Directed Activities Related to Texts (DARTs), group projects, group debates, and animated video discussions containing multiple representation models in 
chemistry learning. Activities using DARTs have previously been reported to increase mastery of chemical concepts (Imaduddin \& Haryani, 2019).

\section{Discussion}

In principle, the development of Simple Chemistry course for pre-service islamic elementary school teachers has been adjusted to the expected performance of the study program. Chemical learning for pre-service islamic elementary school teachers is approached with several domain. De Jong (2006) distinguishes four different domains that can be utilized to offer a textual approach to chemistry learning:

1) Personal domain: Connecting chemistry to the student's personal life.

2) Professional practice domain: Provide information and background for future work.

3) Professional domains and technology: Enhance students' understanding of science and technology applications.

4) Social and community domains: Preparing students to become, in the future, responsible citizens.

In using De Jong's four focus, we can get all the generals curriculum orientation can be used for chemistry learning. This general orientation offers a textual approach to start lessons from, but orientation can also be used as a guiding principle for structuring the entire curriculum (Eilks et al., 2013):

1) The structure of disciplinary orientation: The inner structure of the academic (chemical) scientific discipline is used for curriculum structuring. The basic focus is to study scientific theories and facts and their relationships with one another. The school's chemical curriculum looks like a light version of a university textbook in common chemistry.

2) History of science (chemistry) orientation: The history of science is used to study scientific content as it appears in the past, but also to enable learning about its chemical properties and historical developments in the means of emphasizing the Knowledge Development in Chemistry curriculum. Lesson plans are often planned throughout the episode of chemical history.

3) Orientation of everyday life: Questions from everyday life are used to gain entry into the learning of chemistry. This approach is chosen so that chemistry learning has meaning for students. Students should feel the need to know about chemistry to overcome their life. For example, use of household cleaners is taken as a context for approaching acidbase chemicals.

4) Environmental Orientation: Environmental issues are used to provoke science learning behind this issue, but also about environmental protection questions. An example might be a lesson plan on clean drinking water, air pollution, or acid rain.

5) Technology and industrial orientation: The development of chemical and industrial technology is addressed to learn about chemistry and its applications. The teaching in a broader view focuses on the interaction of science and technology in society. For example. crude oil distillation or industrial metal production is important as a problem for chemical lesson plans.

6) Orientation of socio-scientific issues: The socio-scientific problem forms the starting point of chemistry learning, which allows students to develop general education skills to prepare them to become responsible citizens in the future. An example is the debate surrounding climate change or the effects of biofuels on the economy, ecology and society.

Johnstone (1993) has presented a highly influential analysis of chemical characteristics by differentiating them into three domains of meaning: macroscopic domains, submicroscopic domains, and symbolic domains. Their relationship is illustrated in Figure 1.

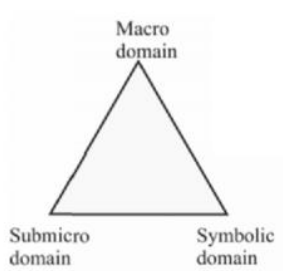

(a)

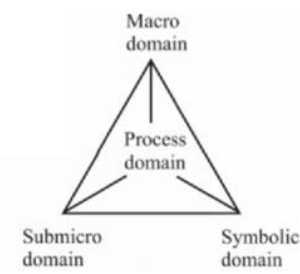

(b)
Figure 1. Relationship between domains of meaning: (a) basic version, (b) extended version

Macroscopic domain (later referred to as macro domain) is related to observable chemical phenomena, perceived by other senses. For example, Sodium chloride (known as table salt) is described as a dense crystal with a salty taste and water-soluble. The submicroscopic domain (referred to as submicro domain) leads to particle entities, especially atoms, molecules, ions and electrons, as well as their arrangements. For example, the 
constituent particles of solid sodium chloride can be described as sodium and chlorine ions arranged in regular ionic lattices. The symbolic domains mainly relates to representations in terms of formulas, reaction equations, charge signs, and the like. For example, the dissolution of sodium chloride in water can be described as $\mathrm{NaCl}_{(\mathrm{s})}+\mathrm{H}_{2} \mathrm{O}_{(\mathrm{l})} \rightarrow \mathrm{Na}^{+}{ }_{(\mathrm{aq})}+\mathrm{Cl}^{-}$(aq).

Dori \& Hameiri, 2003 proposed an extended version of the Johnstone meaning triangle by adding the fourth domain (see Figure 1b). Process domains mainly relate to the way any reaction takes place, such as breaking and bonding, energy changes, and so on. These can be attributed to each of the other three domains to gain deeper insight into the chemistry field. In the dissolution example, this

Table 1. Linkages between chemical contexts, chemical content, Islamic values, and Sustainable Development

\begin{tabular}{|c|c|c|c|c|}
\hline \multirow{3}{*}{$\begin{array}{l}\text { Atmospheric } \\
\text { Chemistry }\end{array}$} & The air we breathe & \multirow{3}{*}{$\begin{array}{l}\text { Matter and } \\
\text { particle: } \\
\text { a. Atomic }\end{array}$} & \multirow{3}{*}{$\begin{array}{l}\text { And We made the sky } \\
\text { a protected ceiling, } \\
\text { but they, from its } \\
\text { signs, are turning } \\
\text { away. (QS. Al- } \\
\text { Anbiya, (21):32). }\end{array}$} & \multirow{3}{*}{$\begin{array}{l}\text { Sustainable } \\
\text { Development } \\
\text { Attitudes for } \\
\text { Project } \\
\text { Designing interior } \\
\text { and exterior of the } \\
\text { house, and } \\
\text { choosing the type } \\
\text { of plants that are } \\
\text { responsive to air } \\
\text { pollutants }\end{array}$} \\
\hline & $\begin{array}{l}\text { Protecting Ozon } \\
\text { Layer }\end{array}$ & & & \\
\hline & $\begin{array}{l}\text { The chemistry of } \\
\text { global warming }\end{array}$ & & & \\
\hline \multirow[t]{2}{*}{$\begin{array}{l}\text { Hydrospheric } \\
\text { Chemistry }\end{array}$} & $\begin{array}{l}\text { The water we } \\
\text { drink }\end{array}$ & $\begin{array}{l}\text { The properties of } \\
\text { Solution: }\end{array}$ & \multirow{2}{*}{$\begin{array}{l}\text { And We sent down } \\
\text { from the sky water } \\
\text { (rain) in (due) } \\
\text { measure, and We gave } \\
\text { it lodging in the earth, } \\
\text { and verily, We are } \\
\text { Able to take it } \\
\text { away.[Al- } \\
\text { Mu'minun(23):18] }\end{array}$} & \multirow{2}{*}{$\begin{array}{ll}\text { Creating a simple } \\
\text { water } & \text { purifier } \\
\text { design } & \end{array}$} \\
\hline & $\begin{array}{l}\text { Technology of } \\
\text { water treatment } \\
\text { plant }\end{array}$ & $\begin{array}{l}\text { a. Physical } \\
\text { characteristics } \\
\text { of water } \\
\text { b. Acid and Base } \\
\text { c. Acid rain and } \\
\text { water cycle } \\
\text { d. Mineral and } \\
\text { Demineral } \\
\text { Water }\end{array}$ & & \\
\hline $\begin{array}{l}\text { Soil } \\
\text { Chemistry }\end{array}$ & Soil damage & $\begin{array}{l}\text { Elements in the } \\
\text { Soil } \\
\text { a. The formation } \\
\text { of the soil } \\
\text { b. Colloid in the } \\
\text { soil } \\
\text { c. Biogeochemical } \\
\text { Cycle in the } \\
\text { soil }\end{array}$ & $\begin{array}{l}\text { And the good land - } \\
\text { its vegetation emerges } \\
\text { by permission of its } \\
\text { Lord; but that which } \\
\text { is bad - nothing } \\
\text { emerges except } \\
\text { sparsely, with } \\
\text { difficulty. Thus do } \\
\text { We diversify the signs } \\
\text { for a people who are } \\
\text { grateful. [Al- } \\
\text { Mu'minun(7):58] }\end{array}$ & $\begin{array}{l}\text { Designing simple } \\
\text { experiment for } \\
\text { Phytoremidiation }\end{array}$ \\
\hline
\end{tabular}

domain is associated with ion lattice disorder by water molecules and rearrangement and ion hydration leading to an endothermic reaction $(\Delta \mathrm{H}$ positive).

As an effort to infuse Islamic values and aspects of sustainable development, the lectures for preservice islamic elementary school teachers were still on the focus of mastery of chemical contents by contextualizing various phenomena around them related to environmen. Thus, the chemistry lectures were set with the theme of atmospheric chemistry, hydrosphere chemistry, and chemistry in the soil. The linkages between chemical contexts, chemical content, islamic values, and sustainable development is shown in Table 1. 
Based on pedagogical planning, lesson plans are divided into four stages (Table 2). In the first stage is the contact phase, students are faced with the context, for example Ozone as a blessing from God. At this stage brainstorming on previous ideas and knowledge about the topic "matter and particles". In the second stage, the curiosity and planning phase is carried out in the form of collecting and compiling questions that appear in the first stage in such a way that they can be overcome and answered correctly in the third stage of elaboration. This second phase is done by compiling a mindmap and gathering questions to understand the process of ozone formation and its relationship to air quality parameters. In the elaboration phase, pre-service teachers learnt how to protect the ozone layer and the chemicals associated with global warming. Thus, pre-service teachers can recognize connections to their own contexts and questions and consider chemistry useful and meaningful to them. In the final stage, content is examined in more depth and woven into other knowledge, related to the context that has been discussed previously and the content learned. This phase aims to connect chemistry with a broader context, for example in the selection of plants that can overcome gas pollutant particles that are suitable for indoor and outdoor.

Tabel 2. The four phase of Chemistry Instruction on the example of Atmospheric Chemistry.

\begin{tabular}{lll} 
Phase & Activities & $\begin{array}{l}\text { Focus of Domain of } \\
\text { Meaning }\end{array}$ \\
\hline Phase of contact & $\begin{array}{l}\text { Story: Ozone as a mercy from Allah } \\
\text { Brainstroming on students ideas and prior- } \\
\text { knowledge on the topic 'matter and particle' }\end{array}$ & $\begin{array}{l}\text { Macro domain } \\
\text { Symbolic domain }\end{array}$ \\
\hline $\begin{array}{l}\text { Phase of curiosity } \\
\text { and planning }\end{array}$ & $\begin{array}{l}\text { Structuring with mindmaps } \\
\text { Learners are required to understand the } \\
\text { ozone-forming diagram and observe the } \\
\text { ozone-forming animation video Collecting } \\
\text { student's question }\end{array}$ \\
& $\begin{array}{l}\text { Submicro domain } \\
\text { - Find out about air quality parameters }\end{array}$ \\
& $\begin{array}{l}\text { bollecting students' questions } \\
\text { c. Planning the work }\end{array}$
\end{tabular}

3. Phase of elaboration Learning on how to protect ozon layer and the Process domain chemistry of global warming.

4. Phase of deepening Presenting of interior and exterior design of the Macro domain and networking house, and choosing the type of plants that are responsive to air pollutants

Note: Adapted from (Eilks et al., 2013)

The relevance of the material presented in the context of atmospheric chemistry with the aspects of Sustainable Development can be seen in Figure 1. On the economic aspect, the project approach presented is that the ecohousing design leads the pre-service teacher to provide solutions related to the selection of materials for environmentally friendly buildings and pollutant-responsive plant species. Environmental aspect, can be seen on the issues presented for solving the problem that is about forest fires and associated with the fatwa of Majelis Ulama Indonesia which has been issued before, as seen in Figure 2. On the social aspect, can be seen on how the attitude of learners in an effort to preserve the environment. There are several competencies of science learning material that can be associated with MUI fatwa such as additives, addictive-psychotropic substances, and environmental pollution. It can be implemented with SETS (ScienceEnvironment-Technology-Society) learning design based on the Islamic aspect. Cognitive, affective, and social-cultural domains in 21st Century Skills can be grown in tandem with the growth of the spiritual domain (Imaduddin \& Khafidin, 2018). 


\section{Problem 1}

On January 27, 2016, MUI issued a fatwa namely Fatwa MUI No. 30 of 2016 on Laws of Forest and Land Burning and Control.

1) Try to link the MUI ban in intentional and irresponsible forest burning, with the following aspects:

a. Depletion of the ozone layer!

b. The thicker the greenhouse gas layer!

(Note: Associate with aspects of $\mathrm{O} 2$ gas molecules and $\mathrm{CO} 2$ compounds in the air)

2) As an individual who is part of nature, what concrete steps can you take to maintain the air quality around you!.

Figure 2. Problems presented in chemistry learning for pre-service islamic elementary school teachers.

Based on the results of CET-SD conducted by pre-service islamic elementary school teachers, the results indicated the strengthening of the literacy that was owned by looking at the number of categories of learners who have strong categories. The results can be seen as in Figure 3. There have been better changes in the chemistry literacy of pre-service teachers in the first and second sessions. The number of categories "strong" and "medium" increased.

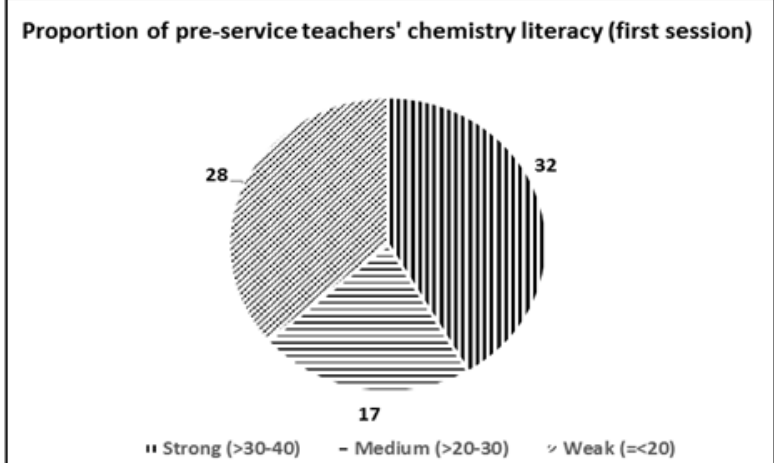

(a)
Proportion of pre-service teachers' chemistry literacy (second session)

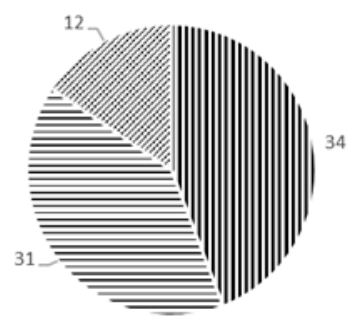

II Strong $(>30-40) \quad=$ Medium $(>20-30) \quad$ "Weak $(=<20)$

\section{(b)}

Figure 3. Diagram showing changes in the proportion of pre-service teacher teacher's chemistry literacy categories $(\mathrm{N}=77)$. (a) first session with mean $=27.5$; (b) second session with mean $=29.9$; maximum score $=40$

The link between Islamic values and chemistry and the environment (in this case sustainable development) was well understood by pre-service teachers. Nevertheless, there were some challenges in teaching chemical content for pre-service islamic elementary school teachers based on the learning that has been implemented. Some of the challenges were as follows:

1. Difficulties with the relation between macro domain and submicro domain. For instance, the air in the gaseous state consists of various gas particles, having an irregular arrangement of particles and the distances between the particles very far compared to solids and liquids.

2. Difficulties with the relation between symbolic domain and macro or submicro domain. An example of the difficulty experienced by a prospective teacher is as in solving the problem in Figure 4. The addition of phase index on the formula of the compound or element molecule, is often not interpreted as a change in the phase of the substance. 


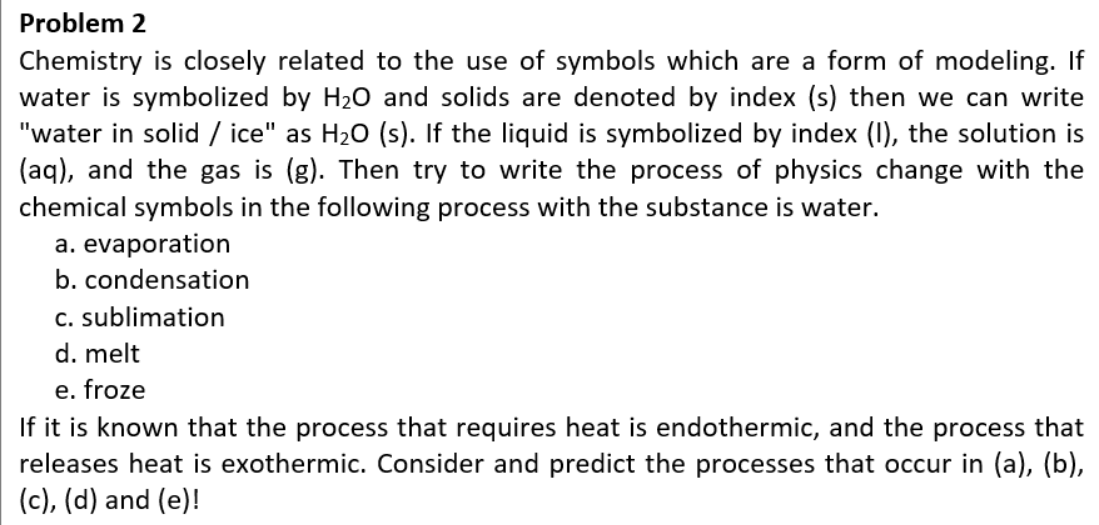

If it is known that the process that requires heat is endothermic, and the process that releases heat is exothermic. Consider and predict the processes that occur in (a), (b), (c), (d) and (e)!

Figure 4. The problems related to the symbolic domain.

3. Difficulties with models. The case example was an understanding of animations related to the ozone layer model and the greenhouse effect. Difficulties occur due to previous knowledge possessed by preservice teachers.

\section{Conclusion}

In the process of infusing Islamic values and aspects of sustainable development, the lectures for pre-service islamic elementary school teachers were still on the focus of mastery of chemical contents. The lectures were set with the theme of atmospheric chemistry, hydrosphere chemistry, and chemistry in the soil. Based on pedagogical planning, lesson plans are divided into four stages, consisting of (1) phase of contact; (2) phase of curiosity and planning; (3) phase of elaboration; and (4) phase of deepening and networking.

Based on the results of CET-SD conducted by pre-service islamic elementary school teachers, the results indicated the strengthening of the literacy that was owned by looking at the number of categories of learners who have strong categories. The relationship between Islamic values and chemistry and the environment was well understood by preservice teachers. Nevertheless, there were some challenges in teaching chemical content for preservice islamic elementary school teachers based on the learning that has been implemented. Although, some challenges in teaching chemical content for pre-service islamic elementary school teachers were found regarding with (1) difficulties with the relation between macro domain and submicro domain; (2) difficulties with the relation between symbolic domain and macro or submicro domain; (3) difficulties with models.

\section{References}

Ary, D., Jacobs, L. C., Sorensen, C., \& Razavieh, A. (2006). Introduction to Research in Education.

Burmeister, M., Rauch, F., \& Eilks, I. (2012). Education for Sustainable Development (ESD) and secondary school chemistry education. Chemistry Education Research and Practice, 13, 59-68.

Clark, J. S., \& Singh, K. (2016). Voices from Religions on Sustainable Development. (K. Singh \& J. S. Clark, Eds.). Berlin: the German Federal Ministry for Economic Cooperation and Development (BMZ).

De Jong, O. (2006). Making chemistry meaningful: conditions for successful context-based teaching. Educación Química, (17), 215-226.

Dori, Y. J., \& Hameiri, M. (2003). Multidimensional analysis system for quantitative chemistry problems: Symbol, macro, micro, and process aspects. Journal of Research in Science Teaching, 40, 278-302.

Eilks, I., Rauch, F., Ralle, B., \& Hofstein, A. (2013). How to Allocate The Chemistry Curriculum Between Science and Society. In I. Eilks \& A. Hofstein (Eds.), Teaching Chemistry - A Studybook: A Practical Guide and Textbook for Student Teachers, Teacher Trainees, and Teachers (pp. 136). Rotterdam/ Boston/ Taipei: Sense Publishers.

Imaduddin, M. (2018). Membingkai Warisan 
Budaya Indonesia dan Nilai-nilai Islam dalam Science Education for Sustainable Development. In Proceedings of Annual Conference for Muslim Scholars, (Series 1) (pp. 489-500). https://doi.org/10.1002/sce.10113.3

Imaduddin, M., \& Haryani, S. (2019). Lembar Kerja Directed Activities Related to Texts (DARTs) Bermuatan Multipel Level Representasi untuk Meningkatkan Kemampuan Berpikir Kritis Calon Guru Kimia. Jurnal Inovasi Pendidikan Kimia, 13(1), 2254-2267.

Imaduddin, M., \& Khafidin, Z. (2018). Ayo Belajar IPA dari Ulama: Pembelajaran Berbasis Sosi-Scientific Issues di Abad ke-21. Thabiea: Journal of Natural Science Teaching, 01(02), 102-120.

Johnstone, A. H. (1993). The Development of Chemistry Teaching. Journal of Chemical Education, 70, 701-705.

Moore, F. M. (2008). The Role of the Elementary Science Teacher and Linguistic Diversity. Journal of Elementary Science Education, 20(3), 4961. https://doi.org/10.1007/BF03174708

NRC. (2009). Learning Science in Informal Environments: People, Places, and Pursuits. Washington: National Academies Press.

Rauch, F. (2004). Education for sustainability: A regulative idea and trigger for innovation. In W. Scott \& S. Gough (Eds.), Key issues in sustainable development and learning: A critical review (p. 149151). London: Routledge Falmer.

UNESCO. (2006). Framework for the UNDESD International Implementation Scheme. Paris.

Vygotsky, L. S. (1986). Thought and Language. Cambridge. MA: MIT. 